\title{
Oral Ketamine Use for Lumbar Puncture in Children Undergoing Intrathecal Chemotherapy in a Developing Country
}

\author{
Adigun $\mathrm{Ta}^{1 *}$, Brown $\mathrm{Bj}^{2}$, Amanor Boadu $\mathrm{Sd}^{1}$ \\ ${ }^{1}$ Department of Anaesthesia, College of Medicine, University of Ibadan, Nigeria \\ ${ }^{2}$ Department of Pediatrics, College of Medicine, University of Ibadan, Nigeria
}

Submission: May 21, 2018; Published: July 16, 2018

*Corresponding author: Adigun Tinuola Abiodun, Department of Anaesthesia, College of Medicine, University of Ibadan, Ibadan, Nigeria, Email: tonitomi2005@yahoo.co.uk

Abstract

Background: Ketamine is an anaesthetic agent that has both sedative and analgesic properties. Different routes of administrations of ketamine have been found effective for sedation in children undergoing painful invasive procedures. The oral route is gaining popularity for procedural sedation in children. The objectives of the study were to compare the efficacy and safety of oral ketamine $10 \mathrm{mg} / \mathrm{kg}$ with $15 \mathrm{mg} / \mathrm{kg}$ for sedation in paediatric oncology patients undergoing lumbar puncture for chemotherapy.

Methods: This was a double blind randomized study. Children presenting for intrathecal chemotherapy between 1 and 10 years of age were randomly assigned into 2 groups of either $10 \mathrm{mg} / \mathrm{kg}$ of oral ketamine or $15 \mathrm{mg} / \mathrm{kg}$, each mixed in a $25 \%$ glucose solution. Efficacy was assessed by onset time of maximum sedation and success rate of the sedation while safety was assessed by monitoring changes in heart rate, blood pressure and oxygen saturation.

Results: Thirty children (18 with retinoblastoma and 12 with Burkitt lymphoma) were recruited into the study with 15 children assigned into each group. There was no difference in demographic data between the two groups. The mean onset time of maximum sedation was $36.7 \pm$ 3.7 minutes in $15 \mathrm{mg} / \mathrm{kg}$ compared with $47.1+2.8$ minutes in the $10 \mathrm{mg} / \mathrm{kg}(\mathrm{p}=0.01)$. Thirteen $(86.7 \%)$ children were treated with additional IV ketamine in the $10 \mathrm{mg} / \mathrm{kg}$ group compared with only $3(20 \%)$ in the $15 \mathrm{mg} / \mathrm{kg}$ group $(\mathrm{P}=0.01)$ in order to achieve the desired sedation. No patient had hypertension or desaturation but tachycardia, nystagmus and hypersalivation were found equally in both groups.

Conclusion: Oral ketamine $15 \mathrm{mg} / \mathrm{kg}$ is a better sedative than $10 \mathrm{mg} / \mathrm{kg}$ in children undergoing lumbar puncture for chemotherapy. Keywords: Pediatric oncology; Pharmacology and sedation

\section{Introduction}

Paediatric oncology patients may require lumbar puncture for the administration of chemotherapy. Fears of repeated pain can be stressful and may produces long term psychological trauma in the tender minds of young children [1]. A safe, fast and atraumatic premedication can be considered before painful invasive procedures in order to allay anxiety and produce analgesia and amnesia in children [2]. An ideal sedative agent for children should be safe, easy to administer, have a rapid and a predictable onset of action, constant efficacy, short duration of action, easy reversibility, with minimal cardiovascular and respiratory effect and produce amnesia and analgesia. It should also lack significant adverse effects and its route of administration should cause no pain [3]

The oral route is the physiological route and is the one most preferred by children compared to intramuscular or rectal route [4]. Oral midazolam is one of the most commonly used agents for procedural sedation in children used in both in the developing and developed countries [4]. It is characterized by fast onset of action, amnesia, muscle relaxation and sedation but lacks analgesic properties. Thus, it may not be a sufficient sedative on its own therefore it is frequently used with opioid or ketamine for procedural pain [4]. However, Ketamine is another sedative that is popular mostly in the developing countries for sedation, it is a 2-0-chlorophenyl 2-methylamine cyclohexine hydrochloride, a phencyclidine derivative. It provides sedation and analgesia. The analgesic effect is produced by interacting with multiple binding sites in both peripheral and central nervous systems. These actions are mediated via N Methyl D-Aspartate (NMDA) and nonNMDA receptors [5].

Ketamine can be administered by the intravenous, intramuscular and oral routes. There are increasing reports on safety and efficacy of oral ketamine for painful invasive procedures 
such as in the repair of laceration in the emergency department [6], in alleviating procedure-related distress in paediatric oncology patients, [7] in dental procedures and in dental treatment [8,9]. Different doses of oral ketamine have been used solely or in combination with oral midazolam with good response [6-9]. Raman and Deshmukh compared three different doses of oral ketamine, $6 \mathrm{mg} / \mathrm{kg}, 8 \mathrm{mg} / \mathrm{kg}$ and $10 \mathrm{mg} / \mathrm{kg}$ for invasive procedures like lumbar puncture, bone marrow aspiration, liver and kidney biopsy 10 Their result showed that ketamine $10 \mathrm{mg} / \mathrm{kg}$ provided a better sedation and analgesia in children undergoing invasive procedures compared to $6 \mathrm{mg} / \mathrm{kg}$ and $8 \mathrm{mg} / \mathrm{kg}$ [10]. Amanor Boadu and Soyannwo compared $5 \mathrm{mg} / \mathrm{kg}$ of oral ketamine with $0.5 \mathrm{mg} / \mathrm{kg}$ oral midazolam as oral premedication. Although both drugs produced satisfactory sedation in the children without psychic emergence, $50 \%$ of the patients with oral ketamine arrived at induction room awake but calm [11].

Tobias et al. [7] administered oral ketamine $10 \mathrm{mg} / \mathrm{kg}$ to 35 children and adolescents and found oral ketamine $10 \mathrm{mg} / \mathrm{kg}$ to adequately provide sedation in children undergoing invasive procedures. Roelofse et al. [12] found that oral ketamine $12.5 \mathrm{mg} / \mathrm{kg}$ was more effective than standard oral premedication (Trimeprazine, physeptone linctus and droperidol) during a dental procedure in 60 children. Cetina also reported that rectal or oral administration of $15 \mathrm{mg} / \mathrm{kg}$ of ketamine was more effective than intramuscular or intravenous ketamine injection [13]. Oral ketamine has been used for many procedures but available data using higher oral ketamine dose in Nigeria is sparse. The aim of the study was to assess the efficacy and safety of oral ketamine $10 \mathrm{mg} / \mathrm{kg}$ compared with $15 \mathrm{mg} / \mathrm{kg}$ for sedation before lumbar puncture in children undergoing intrathecal chemotherapy.

\section{Patients and Methods}

This was a prospective randomized study on sedation with oral ketamine for children scheduled for intrathecal chemotherapy via lumbar puncture. Ethical approval was obtained from the Ethics Committee of the University of Ibadan/ University College Hospital, Ibadan. All patients scheduled for intrathecal chemotherapy during the study period whose parents gave consent were recruited into the study. The study was carried out in the Paediatric wards of the University College Hospital, Ibadan, Nigeria. After each child was seen, a history was obtained especially a history of previous allergy to ketamine. Physical examination was then performed including the patient's weight and fundoscopy to exclude features of raised intracranial pressure. Each child was fasted for 6 hours prior to the procedure.

The children were allocated randomly into 2 groups by a computer generated number; Group A received $10 \mathrm{mg} / \mathrm{kg}$ while group B received $15 \mathrm{mg} / \mathrm{kg}$. The drug solution was prepared by a senior registrar in the Department of Anaesthesia who was not involved in the study; his job was to mix the injectable ketamine according to the weight of the patient with $5 \mathrm{ml}$ of $25 \%$ glucose solution and hand it over to the investigator. The investigator was blinded to the treatment regimen and another independent person observed each patient for acceptability of the oral preparation, onset of sedation, response to lumbar puncture and any side effects. Ketamine hydrochloride $50 \mathrm{mg} / \mathrm{ml}$ injection made by JAWA Pharmaceutical ${ }^{\circledR}$ comes in a colorless liquid solution and $5 \mathrm{ml}$ of $25 \%$ glucose was added to make an oral preparation to mask the bitter taste of the drug, which was administered to the patient and when the child was sedated, the parent could then leave. Lumbar puncture was done under aseptic conditions by the pediatrician. After the intrathecal chemotherapy injection, the patient was placed in the left lateral position until awake.

Availability of resuscitation drugs like adrenaline, hydrocortisone, chlorpheniramine, diazepam and atropine was ensured. Appropriate size laryngoscope blades, endotracheal tubes, oxygen source, bag and mask for ventilation were also made available. Oxygen saturation and heart rate were monitored with a pulse oximeter continuously and blood pressure was recorded every 5 minutes until 30 minutes after the procedure was over. The sedation was assessed using the Ramsay sedation score. Ramsay Sedation Score (RSS) included RSS1: Patient is anxious and agitated or restless or both, RSS 2: Patient is cooperative, oriented and calm, RSS 3: Patient responds to command only, RSS 4: Patient exhibits brisk response to glabella tap or loud auditory stimulus, RSS 5: Patient exhibits sluggish response to glabella tap or loud auditory stimulus, RSS 6 . No response. If the sedation score was between 1 and 3, intravenous ketamine of $0.5 \mathrm{mg} / \mathrm{kg}$ was administered. Atropine $0.02 \mathrm{mg} / \mathrm{kg}$ (intravenous) was given if there was excessive salivation and diazepam $0.1 \mathrm{mg} /$ $\mathrm{kg}$ (intravenous) if there was agitation. Data collected included the demographic data, dose of ketamine, onset of sedation, blood pressure, heart rate, oxygen saturation, presence or absence of hallucination, nystagmus, hypersalivation and abnormal movement.

\section{Statistical Analysis}

Data collected was subjected to statistical analysis using the computer based statistical software package SPSS version 20. Mean and standard deviations was computed for continuous variables while Chi - square was performed as appropriate. $\mathrm{P}$ value less than 0.05 was considered to be statistically significant.

\section{Results}

Table 1: Patient demographic data.

\begin{tabular}{|c|c|c|c|}
\hline & $\begin{array}{c}\text { Oral ketamine } \\
@ 10 \mathrm{mg} / \mathrm{kg}\end{array}$ & $\begin{array}{c}\text { Oralketamine } \\
@ 15 \mathrm{mg} / \mathrm{kg}\end{array}$ & P value \\
\hline $\begin{array}{c}\text { Age in years } \\
\text { (mean } \pm \text { SD) }\end{array}$ & $4.7 \pm 2.96$ & $4.3 \pm 2.96$ & 0.69 \\
\hline $\begin{array}{c}\text { Weight in } \mathrm{kg} \\
\text { (mean } \pm \text { SD) }\end{array}$ & $17.66 \pm 6.17$ & $16.33 \pm 4.71$ & 0.51 \\
\hline $\begin{array}{c}\text { Sex (Male/ } \\
\text { female) }\end{array}$ & $8 / 7$ & $9 / 6$ & \\
\hline
\end{tabular}

\section{SD: Standard Deviation}

Thirty children scheduled for lumbar puncture were recruited into the study. Thirteen patients (43.3\%) were female while the 
remaining $(56.7 \%)$ patients were males. The ages of the children ranged from 2 to 10 years. The age and weight distribution of the cases are shown in Table 1, there was no significant difference in the age, weight and sex distribution in the two groups. Eighteen children $(60 \%)$ of the study had retinoblastoma while 12 children (40\%) had Burkitt lymphoma. Acceptance of the medication was good in all the patients as no child spat out the drug. The mean time to reach a Ramsay sedation score of 2 was $36.7 \pm 3.4$ minutes in the $15 \mathrm{mg} / \mathrm{kg}$ group compared with $47.1+2.8$ minutes in the $10 \mathrm{mg} / \mathrm{kg}$ group $(\mathrm{p}=0.01)$.

Table 2: The mean onset of sedation and the success rate of the two groups.

\begin{tabular}{|c|c|c|c|}
\hline & $\begin{array}{c}\text { Oral ketamine @ } \\
10 \mathrm{mg} / \mathrm{kg} \mathrm{n}=15\end{array}$ & $\begin{array}{c}\text { Oral ketamine } \\
@ 15 \mathrm{mg} / \mathrm{kg} \mathrm{n=15}\end{array}$ & $\begin{array}{c}P \\
\text { value }\end{array}$ \\
\hline $\begin{array}{l}\text { Onset of sedation } \\
\quad(\text { mean } \pm S D)\end{array}$ & $36.66 \pm 1.98$ & $47.13+2.8$ & 0.01 \\
\hline Sedation success & $2 / 15$ & $12 / 15$ & 0.01 \\
\hline
\end{tabular}

Only $2(13.3 \%)$ children out of 15 had adequate sedation to the administered dosage of $10 \mathrm{mg} / \mathrm{kg}$ of oral ketamine without intravenous dosage of ketamine to complete the procedure while $12(80 \%)$ children out of 15 had adequate response to the administered dose of $15 \mathrm{mg} / \mathrm{kg}$ of oral ketamine without intravenous ketamine ( $p=0.01$, Table 2 ). Oxygen saturation was well maintained in all patients but nystagmus, hypersalivation and tachycardia were found equally in both groups while 1 patient vomited in the oral ketamine $15 \mathrm{mg} / \mathrm{kg}$ group and none in oral ketamine $10 \mathrm{mg} / \mathrm{kg}$ group, (Table 3 ).

Table 3: Side effects observed in the two groups.

\begin{tabular}{|c|c|c|}
\hline & $\begin{array}{c}\text { Oral ketamine @ } \\
\mathbf{1 0} \mathbf{m g} / \mathbf{k g}\end{array}$ & $\begin{array}{c}\text { Oral ketamine } \\
\text { @15mg/kg }\end{array}$ \\
\hline Hypersalivation & 10 & 11 \\
\hline Nystagmus & 9 & 9 \\
\hline Tachycardia & 4 & 3 \\
\hline Vomiting & - & 1 \\
\hline
\end{tabular}

\section{Discussion}

This study found that oral ketamine $15 \mathrm{mg} / \mathrm{kg}$ was more effective compared with $10 \mathrm{mg} / \mathrm{kg}$ in children undergoing lumbar puncture for intrathecal chemotherapy. The onset time for maximum sedation was 36 minutes in children with $15 \mathrm{mg} / \mathrm{kg}$ oral ketamine compared to 47 minutes in $10 \mathrm{mg} / \mathrm{kg}$ oral ketamine. Tobias et al. [7] found similar onset time of maximum sedation to be 45 minutes in children being administered $10 \mathrm{mg} / \mathrm{kg}$ oral ketamine [7]. However, this was contrary to other earlier studies reported by Raman et al. [10], Amanor- Boadu \& Soyannwo [11] \& Gutstein et al. [14], they reported onset time of sedation of 20 - 25 minutes irrespective of the dose of oral ketamine given.

This study also showed that the higher dose of $15 \mathrm{mg} / \mathrm{kg}$ was found to be effective in $80 \%$ of patients compared to 13.3 $\%$ in $10 \mathrm{mg} / \mathrm{kg}$ of oral ketamine. Gutstein et al. [14] compared $3 \mathrm{mg} / \mathrm{kg}$ with $6 \mathrm{mg} / \mathrm{kg}$ oral ketamine for patient's acceptance for intravenous cannulation prior to mask induction, the success rate was $13 \%$ in $3 \mathrm{mg} / \mathrm{kg}$ group compared with $57 \%$ in $6 \mathrm{mg} /$ kg. Another study by Rubinstein et al. [15] concluded that oral ketamine $5 \mathrm{mg} / \mathrm{kg}$ did not produce effective sedation for the repair of laceration in accident and emergency Department as all the children needed intravenous ketamine for sedation to complete the procedure [15]. Tobias et al. [7] found $47 \%$ success rate in children who had invasive procedures within 30 minutes and $87 \%$ success after 45 minutes of administration of $10 \mathrm{mg} / \mathrm{kg}$ oral ketamine [7].

In a study by Raman et al. [10] 10 out of 25 children had adequate sedation for the invasive procedure without intravenous ketamine at $6 \mathrm{mg} / \mathrm{kg}, 19$ out of 25 children at $8 \mathrm{mg} / \mathrm{kg}$ and 22 out of 25 children (88\% success) at $10 \mathrm{mg} / \mathrm{kg}$ [10]. Roelofse et al. [12] also compared the effectiveness of oral ketamine $12.5 \mathrm{mg} / \mathrm{kg}$ with Standard Oral Premedication (SOP) comprising of Trimeprazine, physeptone linctus and droperidol during a dental procedure in children, both drugs produced good sedation 60 minutes after drug administration and the sedation success rate was $20 \%$ in SOP group compared with $60 \%$ for oral ketamine [12].

A study by Shewale et al. [16] used oral ketamine $8-15 \mathrm{mg}$ / $\mathrm{kg}$ for radiotherapy, they found inadequate sedation with limb movement in oral ketamine group that necessitated further supplement of sedation to prevent interruption of radiotherapy compared with intramuscular ketamine group [16]. The documented dose of oral ketamine is in the range of $5-10 \mathrm{mg} /$ $\mathrm{kg}$, this dose does not always produce predictable and consistent effect as documented in the literature $[14,15]$ because of low bioavailability of the oral administration which is about $17-20 \%$ with incomplete absorption and extensive first pass metabolism [17]. This would suggest that higher oral dose at $15 \mathrm{mg} / \mathrm{kg}$ is effective and gave higher success rate compared to $5-10 \mathrm{mg} / \mathrm{kg}$. Oral ketamine is currently not available in Nigeria; injectable ketamine given orally in a sweetened mixture to mask the bitter taste has been used in various studies, $25 \%$ glucose solution was used in this study and all the patients had good acceptance of the drug. Amanor-Boadu \& Soyannwo [11] used black currant drink while Raman et al. [10] used 25\% dextrose with good acceptance [10].

In our study, we found no cardio-respiratory compromise in both groups. There were no side effects such desaturation, brochospasm or hypertension. However, the side effects observed were increased secretion, nystagmus and tachycardia in both groups similar to other studies $[10,13]$. The increased secretion did not require any intervention in this study. Prophylactic antisialogogue has been routinely recommended to prevent oral secretion and may presumably cause airway adverse effects [18]. Rugha et al. [10] observed excessive salivation in 13-33\% of patients in their study without antisialogue [10]. Atropine or glycopyrolate can be given orally or intramuscularly with ketamine to prevent increase in secretion. However oral atropine is unpleasant because it has a bitter taste, it also takes 2 hours to 
be active in addition and intramuscular injection defeats the very purpose of oral ketamine.

\section{Conclusion}

Oral ketamine $15 \mathrm{mg} / \mathrm{kg}$ provided a faster sedation with minimal side effects compared with oral ketamine $10 \mathrm{mg} / \mathrm{kg}$. We therefore recommend the use of oral ketamine $15 \mathrm{mg} / \mathrm{kg}$ as an effective and safe dose for sedation in invasive procedure such as lumbar puncture in children.

\section{References}

1. Slifer KJ, Tucker CL, Dahlquist LM (2002) Helping children and caregiver cope with repeated invasive procedures: How are we doing? Journal of clinical psychology in medical setting 9(2): 131-152.

2. Mehrotra A, Chorasia HK, Kothari D, Shrivastsva DC (2000) Oral ketamine for preanaesthetic medication in paediatric patients. Ind J Anaesth 44: 61-62.

3. Meredith JR, O'Keefe KP, Galwankar S (2008) Paediatric procedural sedation and analgesia. Journal of emergency, Trauma and shock 1(2): 88-96.

4. Davies FC, Walters M (1998) Oral midazolam for conscious sedation of children during minor procedures. J Accid Emerg Med 15(4): 244-248.

5. Sinner B, Graf BM (2008) Ketamine. Handb Exp Pharmacol 182: 313333.

6. Howes MC (2004) Ketamine for pediatric sedation and analgesia in emergency department Emerg Med J 21(3): 275-280.

7. Tobias JD, Phillips S, Smith B Mulhern RK (1992) Oral ketamine premedication to alleviate the distress of invasive pediatric oncology patients. Pediatrics 90(4): 537-541.

8. Alfonzo Echeverri EC, Berg JH, Wild TW, Glass NL (1993) Oral ketamine for pediatric outpatient dental surgery sedation. Pediatr Dent 15(3): 182-185.

9. Damle SG, Gandhi M, Laheri V (2008) Comparison of oral ketamine and oral midazolam as sedative agents in pediatric dentistry. Journal of Indian society of pedodontist and preventive dentistry 26(3): 97-101.

10. Raghu Raman TS, Deshmukh J (1999) Brief Reports. Painless invasive procedure. Indian pediatrics 36: 1023-1028.

11. Amanor Boadu SD, Soyannwo OA (2001) Ketamine and midazolam as oral premedication in children. Afr J Biomed Res 4: 13-14.

12. Roelofse JA, Joubert JI, Swart LC, Stander I, Roelofse PG (1996) An evaluation of the effect of oral ketamine and standard oral premedication in the sedation of pediatric dental patients. J Dent Ass S Afri 51(4): 197-201.

13. Cetina J (1982) Smooth induction of anaesthesia in children by means of oral or rectal ketamine dehydrobenzperidol application. Anaesthsist 31(6): 277-279.

14. Gutstein HB, Johnson KL, Heard MB, Gregory GA (1992) Oral ketamine preanaesthetic medication in children. Anesthesiology 76(1): 28-33.

15. Rubinstein O, Barkan S, Breitbart R, Berkovitch S, Toledano M, et al. (2016) Efficacy of oral ketamine compared to midazolam for sedation of children undergoing laceration repair. Medicine 95(26): e3984.

16. Shewale S, Saxena A, Trikha A, Singh M, Sharief A (2000) Oral ketamine for radiotherapy in children with cancer. Indian J Pediatr 67(4): 263266.

17. Chong CC, Schug SA, Page Sharp M, Ilett KF (2006) Bioavailability of Ketamine after oral or sublingual administration. Pain Med 2006; 7(5): 469.

18. Green SM, Roback MG, Krauss B (2010) Anticholinergic and ketamine sedation in children: a secondary analysis of atropine versus glycopyrolate. Acad Emerg Med 17(2): 157-162.

\section{Your next submission with Juniper Publishers will reach you the below assets}

- Quality Editorial service

- Swift Peer Review

- Reprints availability

- E-prints Service

- Manuscript Podcast for convenient understanding

- Global attainment for your research

- Manuscript accessibility in different formats

( Pdf, E-pub, Full Text, Audio)

- Unceasing customer service

Track the below URL for one-step submission https://juniperpublishers.com/online-submission.php 